\title{
Technologies Applied to Wood Heat Treatments, a Review
}

\author{
Tecnologías aplicadas a los tratamientos térmicos en madera, una revisión
}

\author{
R. Acosta-Acosta iD; J. A. Montoya-Arango (iD, E. Joma-da-Silva iD \\ DOI: https://doi.org/10.22517/23447214.22641 \\ Artículo de revisión
}

\begin{abstract}
Heat treatments are carried out on the wood to modify the hygroscopic properties and its dimensional stability. This allows low-grade wood to be used in exposed applications. This document provides a systematized bibliographic review related to the available technologies that allow heat treatment of wood. For this, scientific databases were consulted where previous studies with high temperature drying were found that served as the basis for the development of technologies that are used today. Patent databases were also consulted making the systematic use of the International Patent Classification (IPC) and Cooperative Patent Classification (CPC), the most promising codes were selected according to the histogram analysis. Finally, a marked trend was observed in recent years in the study and development of heat treatments applied to different timber species.
\end{abstract}

Index Terms - Heat, modified, review, technologies, treatment, wood.

Resumen - Los tratamientos térmicos se realizan a la madera con el fin de modificar las propiedades higroscópicas y su estabilidad dimensional. Esto permite que madera de baja calidad pueda ser usada en aplicaciones de libre exposición. Este documento proporciona una revisión bibliográfica sistematizada relacionada con las tecnologías disponibles que permiten realizar tratamientos térmicos en madera. Para esto se consultaron bases de datos científicas en donde se encontraron estudios previos con secado a alta temperatura que sirvió de base para el desarrollo de las tecnologías que se usan en la actualidad. También se consultaron bases de datos de patentes haciendo el uso sistematizado de la Clasificación Internacional de Patentes (CIP) y la Clasificación cooperativa de Patentes (CCP), se seleccionaron los códigos más prometedores de acuerdo con el análisis del histograma. Por último, se observó una tendencia marcada para los últimos años en el estudio y desarrollo de los tratamientos térmicos aplicados a diferentes especies maderables.

Palabras claves- Calor, madera, modificado, revisión, tecnologías, tratamiento.

This manuscript was sent on August 27, 2020 and accepted on June 01, 2021. This work was supported in part by the Universidad Tecnológica de Pereira, Project 9-17-7.

Ricardo Acosta Acosta is Professor of the Technological University of Pereira (e-mail: ricosta@utp.edu.co).

\section{INTRODUCTION}

$\mathrm{W}$ OOD is an orthotropic material and is considered the largest source of lignocellulosic fibers. It is used for manufacturing paper, wood pellets and charcoal as well as for conducting material reinforcement and construction among other activities. For wood to satisfy the construction specifications, one or more treatments must be applied that can be referred to as wood modification. The treatment application is dependent on the purpose of the product, raw material, conversion operations and final cost [1]. Wood modification alters the material to overcome or ameliorate one or more of its disadvantages. Wood treatments can be either passive or active. Passive treatments are conducted when the physical and mechanical properties of a material change without any alteration in its chemistry, whereas active treatments are conducted when the physical and mechanical properties of a material change with an alteration in its chemistry [2].

Wood treatments can be either chemical or Thermo-HydroMechanical (THM) (Fig. 1); any treatment will induce changes in the physical and mechanical and/or chemical properties of wood. The chemical modification of wood can be defined as the reaction of a chemical reagent with the polymeric constituents of wood, resulting in the formation of a covalent bond between the reagent and the wood substrate [2]. There are two chemical modifications that can be referred to as soft and subversive. Soft chemical modification is generally used to prevent deterioration by exposure to environment and to prevent attacks of harmful microorganisms and insects. These treatments can be superficial, such as coatings, or internal, such as impregnations. Subversive chemical modification is generally used to produce raw material and to cause wood modification. The chemical agents that are used in chemical modifications are generally not considered environment friendly.

Jorge Augusto Montoya Arango is Director of Engineering in Sustainable Wood Processes and Professor of the Technological University of Pereira (email: jorgemontoya@utp.edu.co).

Emilin Joma da Silva is Doctoral candidate at University Hamburg. M.Sc. Wood Sciences and Technology at the University Hamburg (e-mail: emilin.joma.da.silva@uni-hamburg.de). 
Some THM treatments are considered to mainly focus on the physical and mechanical changes and are used in manufacturing processes such as wood bonding, forming and densification. Other treatments, such as Heat Treatments (HT), generate internal chemical reactions and can be used to change the color, improve the hygroscopic properties, and increase the dimensional stability of wood. HT worsens the mechanical properties of the material [3]. Further, HT produces thermal modification and can be defined as the application of heat to wood to achieve the desired performance improvement [2].

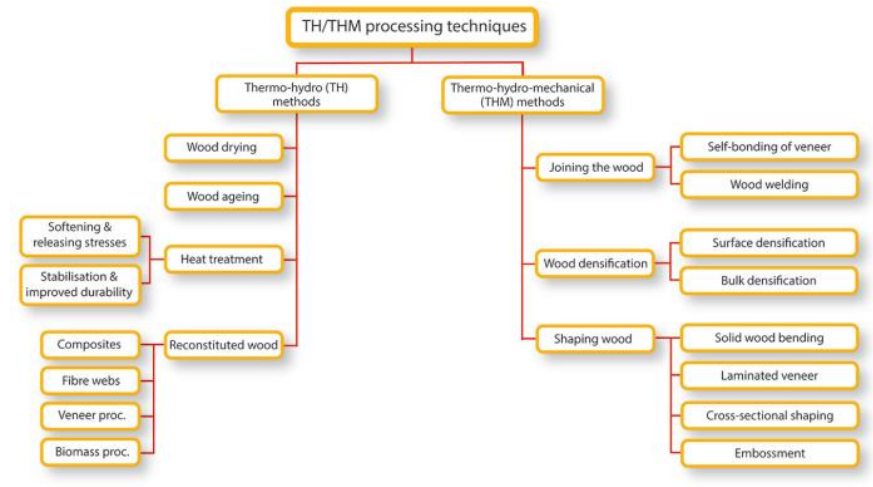

Fig. 1. Wood Modification [3]

HTs exhibit an HT mechanism and provide considerable biological life to wood; further, they also provide dimensional stability, thereby reducing its equilibrium moisture content (EMC) as well as the internal stresses and improving the aesthetics by homogenizing its color. However, HTs decrease the mechanical properties of wood by a maximum of $30 \%$, reduce its density by a maximum of $20 \%$ and the fragility of the material [4]. These treatments can be performed through the pyrolysis and hydrolysis processes. In the pyrolysis process, the systems are open and are maintained at atmospheric pressure and high temperatures; further, the wood must be dried, and the cycles are long time, generate emissions and a lot of energy consumption. In the hydrolysis process, the systems are closed and exhibit high pressures and low temperatures; further, the wood does not need to be dried, the cycles are short, and the emissions and energy consumption are low [5]. During the HT for wood, the material is introduced to temperatures that are close to the pyrolysis temperature in inert environments (without or with little oxygen) for avoiding combustion. Further, the temperature is maintained constant for a given period (during the HT), and, finally, the conditioning is performed (controlled cooling).

The HT technologies that are currently used contain three stages in common (Fig. 2).

- The wood must be preheated. The temperature of the wood is brought close to the temperature at the beginning of the pyrolysis $\left(180^{\circ} \mathrm{C}-230^{\circ} \mathrm{C}\right)$ with a low presence of oxygen for preventing combustion.

- Heat treatment: Wood is exposed to a constant temperature for a given period.

\footnotetext{
${ }^{1}$ Bibliographic database containing abstracts and citations from scientific journal articles.
}

- Conditioning: Wood is brought back to temperatures of lower than $100{ }^{\circ} \mathrm{C}$ to avoid thermal shock when it is exposed to the atmosphere and prevent combustion.

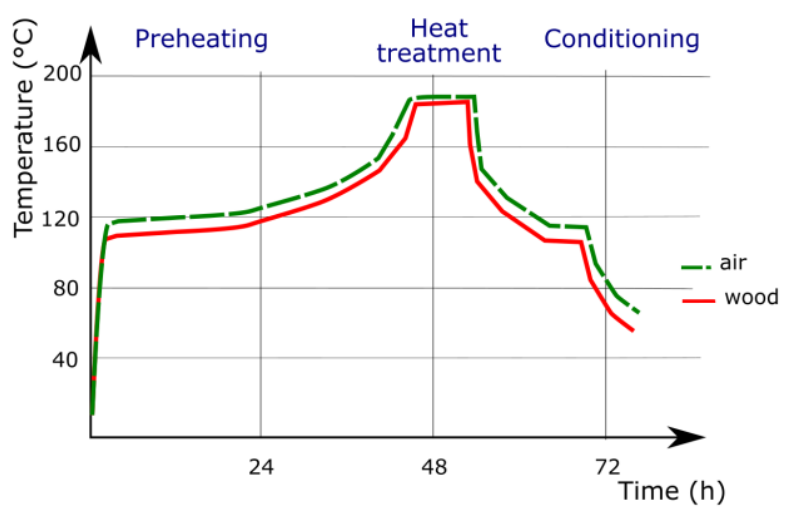

Fig. 2. Example of heat treatment [6]

\section{MATERIALS AND METHODS}

The literature review considered both scientific as well as commercial databases, where the available technologies that were currently used for performing HT of the wood were established. As can be observed from the Scopus database ${ }^{1}$ (Fig. 3 ), in the previous two decades, there has been an increase in research related to wood HT, with the United States, China, the United Kingdom, Germany and Canada having the highest number of publications related to this subject matter (Fig. 4).

This trend reflects a widespread interest in developments that modify wood to improve its durability and dimensional stability. This trend may be attributed to the scarcity of hardwoods or to the restrictions that are currently imposed on the exploitation of some hardwoods.

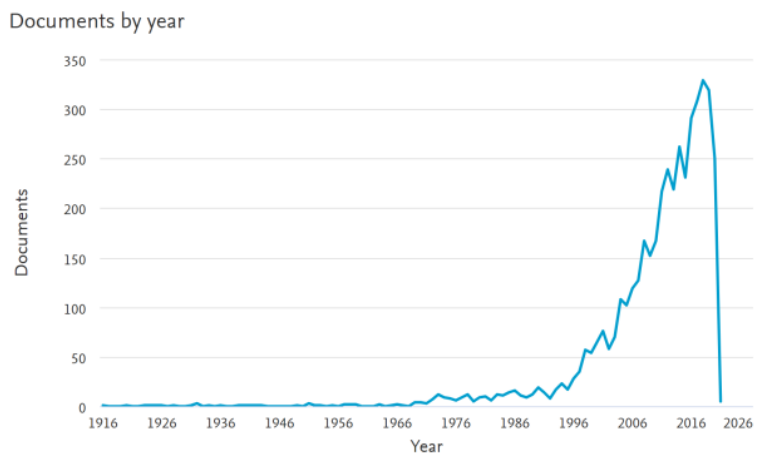

Fig. 3. Trends obtained based on publications related to wood heat or thermal treatments [7] 


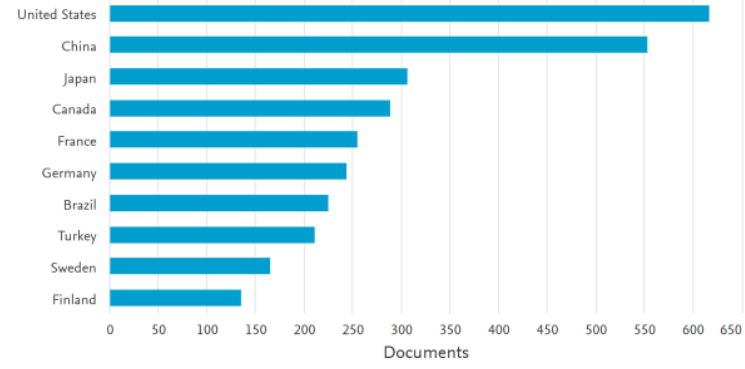

Fig. 4. Countries of origin of the wood heat or thermal treatment publications [7]

For this review, International Patent Classification (CIP) and the Cooperative Patent Classification (CPC)) codes listed below were considered and the most promising codes were selected according to the histogram analysis (Fig. 5). From this search documents related to drying processes, impregnation and thermomechanical treatments were extracted, and it is limited only to thermal treatments applied to wood and some hybrids methods found in the bibliography.

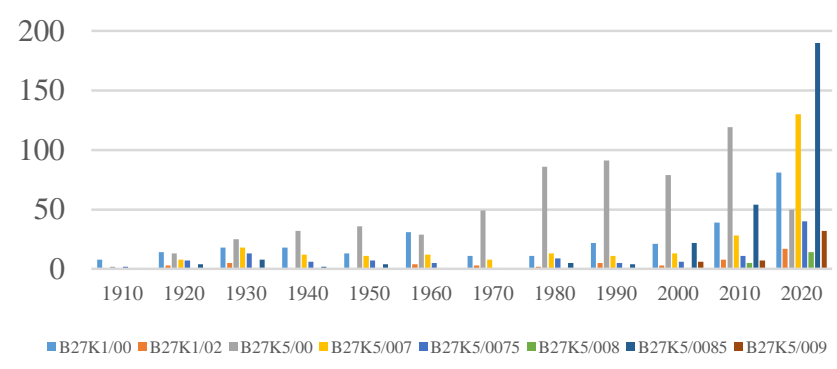

Fig. 5. Histogram of CCP publications

\section{RESULTS AND DISCUSSION}

Several authors have performed various studies since the beginning of the twentieth century, and these studies served as the foundation for developing industrial HT technologies that are currently being used for wood.

Tiemann (1915) observed the effects of different drying methods on the mechanical strength of wood and noticed that drying processes reduced the strength and hygroscopicity in addition to changing the color of the material to a darker hue. However, the reduction in hygroscopicity improved the dimensional stability of wood [8]. Kollmann (1936) used high temperatures and densification by pressure; this process is known as Lignostone ${ }^{\circledR}$ [9] [10]. Stamm and Hansen (1937) performed the initial wood HT in a systematic manner. They reported a reduction in hygroscopicity along with the swelling and contraction of dry wood in treatments using several gases at temperatures lower than the decomposition temperature [11]. This observation was later patented in 1942 under the name of "Antishrink Treatment for Wood" and was related to a procedure that involved subjecting the material to temperatures higher than the drying temperatures $\left(260{ }^{\circ} \mathrm{C}-315.5^{\circ} \mathrm{C}\right)$ using molten metal, welding bath, molten salt or oil as the heating medium for relatively short periods of time (10-120 minutes). The advantage of this method is that it prevents oxidation because oxidation occurs in hot air treatments owing to the presence of oxygen [12]. Subsequently, Stamm et al. (1948) patented a method to form compressed wood for structural purposes. In this method, only the heat, pressure and temperature were considered, and the results were similar or better in terms of strength when compared to wood compressed using resins; however, the results also exhibited low water absorption [13].

Seborg et al. (1952) presented a report to the United States Naval Research Office, which disproved the hypothesis that the stabilization of wood using heat can be attributed to a crosslinked chemical reaction. Their experiments concluded that it was not possible to separate stabilization from the effects of fragility in wood, which limited the applications of the treated wood [14]. Stamm et al. (1955) conducted experiments using lead, tin, and cadmium alloys in proportions of $50 \%, 30 \%$ and $20 \%$, respectively, with a melting point of $150{ }^{\circ} \mathrm{C}$. This improved the heat transfer and minimized oxidation as well as the effects on the mechanical strength of a material, resulting in better dimensional stability; further, it can be concluded that the strength losses are still considerably large for commercial applications [15].

Seborg et al. (1956) investigated the thermal stabilization of compressed wood because spring effect, which attempted to recover its initial volume, was reported during its manufacturing. This technological process was commercially known as "Staypak" and was patented in the United States to prevent free exploitation [13], [16]. Further, Burmester (1973), in Germany, investigated the effects of temperature, pressure and moisture content in closed systems. He devised a controlled pyrolysis mechanism by which the temperature became greater than $180^{\circ} \mathrm{C}$ in an oxygen-free atmosphere. This process was referred to as the Feuchte-Warme und Druck (FWD) process or as the moisture/heat/pressure treatment.

The studies focused on obtaining the drying characteristics and were not commercially successful because of the high initial investment, high operating costs, high temperatures observed during the treatment, consumed energy and atmospheric requirements necessary for preventing combustion.

Subsequently, at the beginning of the 21st century, widespread interest grew in Europe related to the development of wood HT technologies. This interest would further expand to the rest of the world.

There are five technologies that are as follows: Thermowood in Finland, PLATO in Holland, Rectification in France, Oil Heat Treatment (OHT) in Germany [17], and, most recently, Westwood in the United States. Further, other technologies have been derived from improvements to previous technologies by considering the technical patent documents.

Next, we will discuss the HT processes that are observed in scientific and commercial databases:

\section{Feuchte-Warme und Druck Process}

Feuchte-Warme und Druck (FWD) process is a German technology based on the studies conducted by Burmenter in 1973 and Tjeerdsma et al. in 1998, which exhibited that the 
effects of HTs that were performed using saturated steam at low temperatures were like those of the HTs that were performed using superheated steam at high temperatures. This process uses saturated steam as the heat transfer medium at a pressure of 7 $10 \mathrm{bars}$ and at a temperature of $160^{\circ} \mathrm{C}-180^{\circ} \mathrm{C}$. This process is like the PLATO HT process, with the difference being that the steam is produced inside the cell and not outside by a boiler [18].

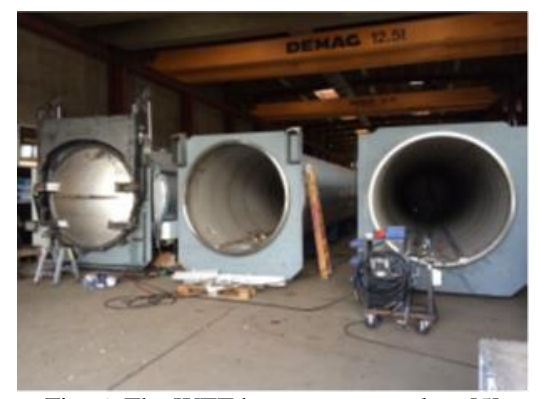

Fig. 6. The WTT heat treatment plant [5]

(1)

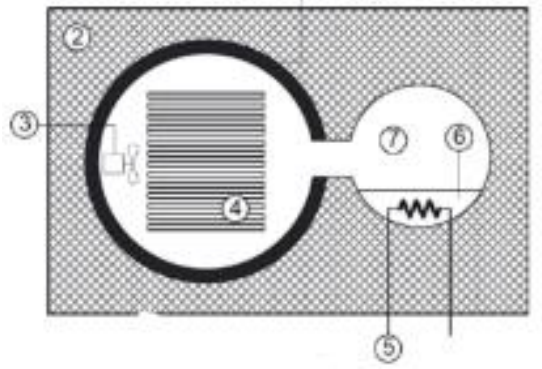

Fig. 7. The Firmolín plant chart [18]

This process has been commercialized by the WTT® and Firmolín ${ }^{\circledR}$ companies in Europe, with a few differences being observed in the construction part of the plants. In the WTT plant (Fig. 6), steam is directly generated by a radiator into the HT chamber. This plant was developed by Kjeld Uhre and Peter Klaas in 1978, who were the owners of the WTT Engineering and Manufacturing Company, founded in 1977 [5]. In the Firmolín plant (Fig. 7), we can observe an HT chamber (4), an autoclave (1), a steam recirculation fan (3), thermal insulation (2) and an internal compartment (7) with water and resistor (5) to have better control of the temperature and steam pressure.

\section{PLATO Process}

This $\mathrm{s}$ a Dutch technology that originated from a study conducted by Shell Research in 1972 by the researcher Herman Ruyter during the oil crisis, which was denominated as PLATO (providing lasting advanced timber option). Herman Ruyter predicted that wood will become decay resistant owing to this process [19]. In 1989, this process was disclosed in a scientific article and was later patented in Europe and the United States in 1993 and 1995, respectively [20] [21].

This process uses water steam as a heat transfer medium and is performed in three stages. In the first stage (hydrothermolysis), green wood or wood that has been previously dried outdoors (Fig. 8) is treated at temperatures ranging from $160{ }^{\circ} \mathrm{C}$ to 190 ${ }^{\circ} \mathrm{C}$ with a slight increase in pressure (pressurized). Further, this process is performed with low oxygenation. The second stage is a drying and curing process that is performed at atmospheric pressure with temperatures ranging from $170{ }^{\circ} \mathrm{C}$ to $190{ }^{\circ} \mathrm{C}$. In this stage, wood is brought to a humidity level of approximately $10 \%$. Finally, the third stage corresponds to the conditioning stage, which comprises cooling of the wood and its introduction to the environmental conditions (Fig. 9) [17] [22].

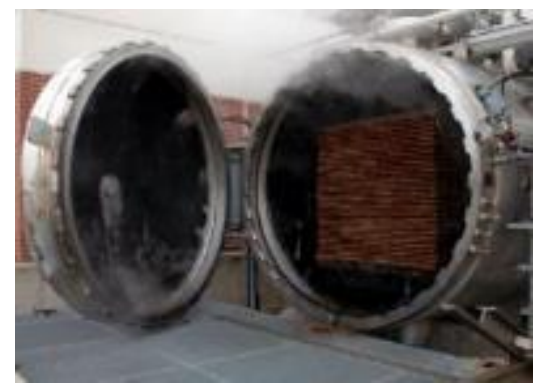

Fig. 8. Introduction of wood that was previously dried outdoors before the PLATO process [19]

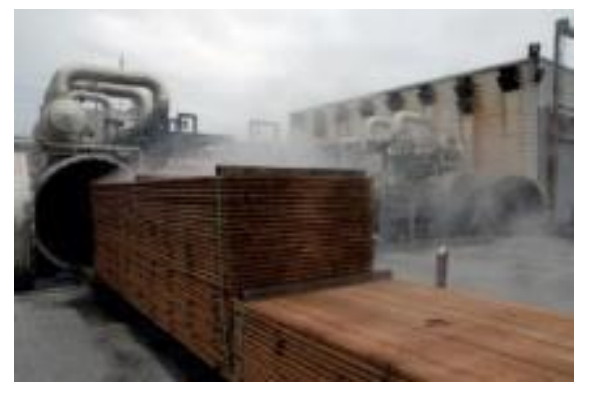

Fig. 9. The heat-treated wood using the PLATO process [19]

The treatment time depends on the type of wood and the wood section, among others.

- Stage 1: Hydrothermolysis for 4 to 5 hours.

- Stage 2: Dried for 3 to 5 days and cured for 14 to 16 hours.

- Stage 3: Conditioning for 2 to 3 days.

\section{Thermowood Process}

This is a registered trademark for a Finnish technology developed by the VTT Technical Research Centre of Finland, which is one of the leading researches and technology organizations in Europe. Wood is heated to a temperature of at least $180{ }^{\circ} \mathrm{C}$ while it is protected with steam to prevent combustion. Further, the steam induces chemical reactions (hydrolysis) that modify the physical, mechanical, and chemical properties of the wood [23].

The Thermowood process can be divided into three stages (Fig. 10 and Fig. 11).

Drying: This phase can also be referred to as high temperature drying and is observed to constitute majority of the treatment. During this phase, the moisture content of the wood becomes close to zero before the HT begins.

Heat treatment: The HT is performed in a closed chamber in which the temperature increases to $185^{\circ} \mathrm{C}$ to $215^{\circ} \mathrm{C}$ depending on the treatment programmed. The HT phase starts immediately 
after the high temperature drying phase is completed. Steam is used during drying, and the HT provides protective steam, thereby preventing combustion. This phase requires 2 to 3 hours.

Conditioning: It is performed after the HT is completed. Wood is cooled in a controlled manner, thereby preventing contact with the external environment to avoid explosions. Further, wood must be rehydrated to levels of $5 \%$ to $7 \%$. This phase requires 5 to 15 hours [23].

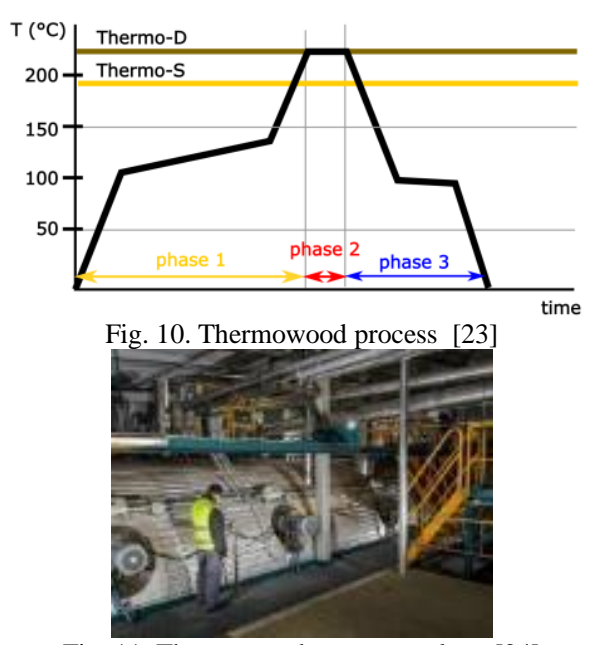

Fig. 11. Thermowood treatment plant [24]

The Thermowood process is mainly intended for two product references, which depend on the temperature at which the treatment is conducted: the Thermowood S for obtaining dimensional stability and the Thermowood D for obtaining durability (Fig. 10).

\section{Bois Perdure Process}

This is a French technology, which is initiated using green wood. The first stage of the process comprises pre-heating the wood to a temperature $\left(100{ }^{\circ} \mathrm{C}\right.$ to $\left.120{ }^{\circ} \mathrm{C}\right)$ with which the free water that is contained in the material will evaporate. The second stage corresponds to a drying process at a high temperature $\left(200{ }^{\circ} \mathrm{C}\right.$ to $\left.240{ }^{\circ} \mathrm{C}\right)$. This ensures the evaporation of residual free water from the previous stage. The third stage corresponds to the HT in which the oxygen content is limited to prevent combustion. Further, during the final stage, the material is cooled by atomizing the water in the combustion chamber and not directly on the treatment chamber. This ensures homogenous cooling of the wood. The duration times $\left(T_{1}, T_{2}, T_{3}\right)$ for each of the stages depends on the species (Fig. 12), the characteristics of the wood and the thickness and conditions of the material caused by the immediately preceding stage [25]. The temperature that is used during the process positively affects the durability of the wood but negatively affects the mechanical resistance [25].

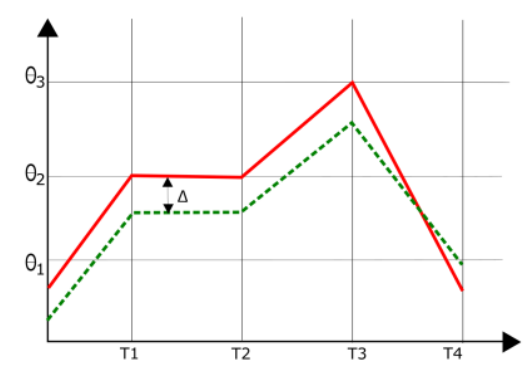

Fig. 12. Heat treatment curve obtained by Bois Perdure [26]

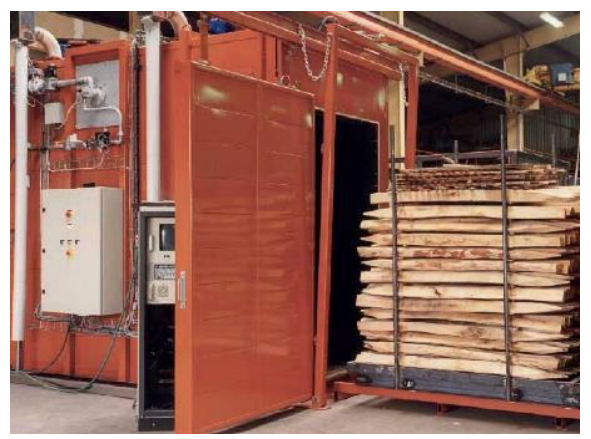

Fig. 13. The Bois Perdure process: treatment kiln [18]

This process was developed by French holding company BCIMBS (Fig. 13). Later, PCI Industry purchased the intellectual property rights to Perdure Technology and, in 2003, opened two plants in Quebec, Canada [18].

\section{Rectification Process}

This is a French technology in which thermolysis (aqueous pyrolysis) is conducted in an atmosphere with inert gas (usually nitrogen). This process is like the Finnish technology, except for the fact that the cell is saturated with an inert gas, which prevents the activation of wood combustion (Fig. 15). This process comprises slow heating of the wood in an atmosphere with less than $2 \%$ oxygen at temperatures ranging from $210{ }^{\circ} \mathrm{C}$ to $240{ }^{\circ} \mathrm{C}$ (Fig. 14) [25].

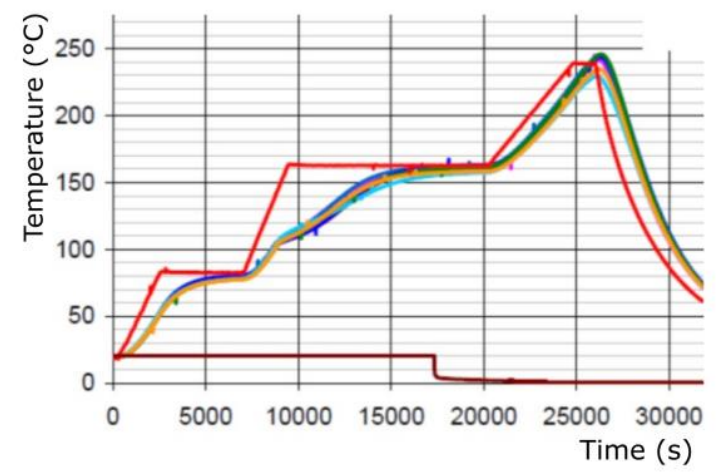

Fig. 14. Heat treatment curve by rectification [26] 


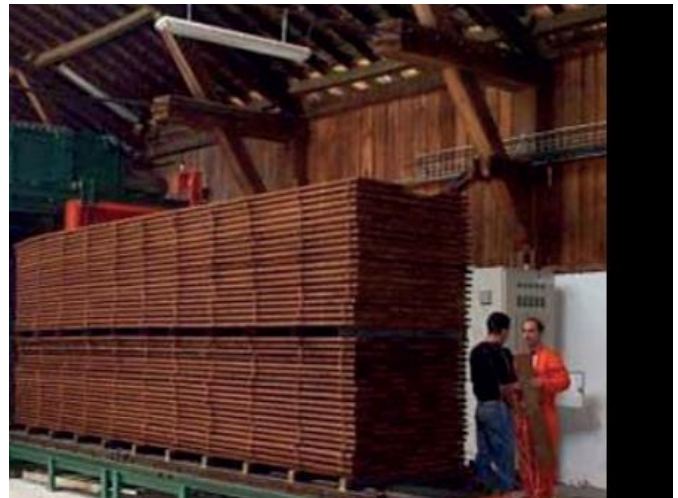

Fig. 15. First kiln for performing the industrial rectification process [18]

This process was developed in France by the National School of Mines of Saint-Etienne in collaboration with the private companies Now S.A., Rey furniture and a boiler manufacturer. The process was commercialized from 1998 to 2003 under the name of Rétibois. Later, in 2007, the company was purchased by Retitech [18].

\section{OHT Process}

This is a German technology that uses hot oil to transfer heat. This process is performed in a pressure vessel (Fig. 17), which contains the wood. Further, vegetable oil is introduced to transfer heat rapidly and homogenously to the wood. In general, this process is performed at temperatures ranging from $180{ }^{\circ} \mathrm{C}$ to $200{ }^{\circ} \mathrm{C}$ (Fig. 16) [16]. This treatment is performed in a closed container, which is initially loaded with wood before introducing hot oil for circulating around the wood. Subsequently, the hot oil is returned to the repository [27].

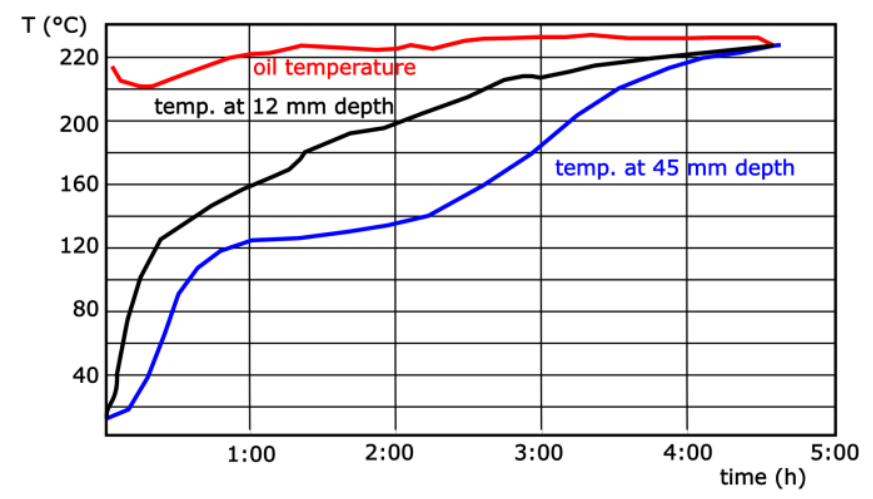

Fig. 16. Oil and wood temperature profiles in the heating stage for timber with a cross section of $90 \times 90 \mathrm{~mm}$ [27]

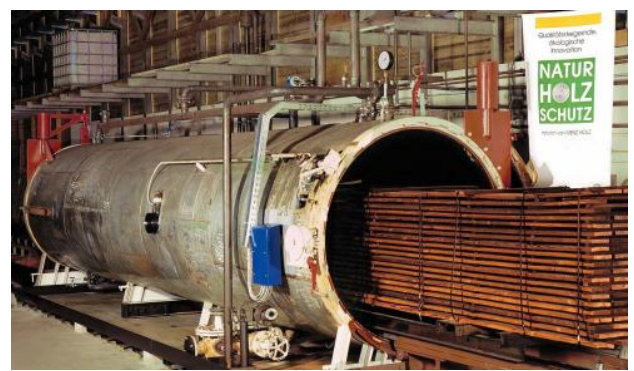

Fig. 17. Pressurised container for conducting the OHT heat treatment [27]

To achieve different levels of HT, different temperatures are applied. For example, to achieve maximum durability and minimum oil consumption, a temperature of $220{ }^{\circ} \mathrm{C}$ is applied; further, to achieve maximum durability and resistance, the temperature is maintained between $180{ }^{\circ} \mathrm{C}$ and $200{ }^{\circ} \mathrm{C}$.

To perform the desired HT to the wood, the temperature must be maintained constant for a period of 2 to 4 hours depending on the section of the wood. The heating stage can require approximately four hours. The total time, including all the stages, is approximately 18 hours for a wood section of $100 \times$ $100 \mathrm{~mm}$ having a length of four meters.

\section{Westwood Process}

This is an American technology that is like Thermowood, and its name originates from the phrase of water extruding the stabilised wood. This technology comprises controlling the HT process through control actions corresponding to the current information parameters, which are introduced as the control signals in a computer system for determining the optimal values of the process parameters [28]. Unlike Thermowood, this technology features improved variable control (Fig. 19) [29].
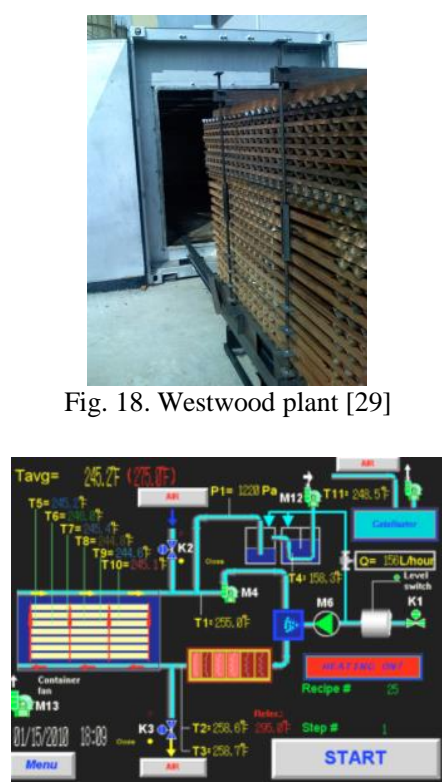

Fig. 19. Supervisory control and data acquisition (SCADA) system [29]

\section{TVT process or TERMOVuoto}

This is an Italian technology that uses a stainless-steel chamber (Fig. 20), where an internal vacuum is created (150 mbar to 350 mbar), which will decrease the point of water evaporation (53 ${ }^{\circ} \mathrm{C}$ to $73{ }^{\circ} \mathrm{C}$ ) and the presence of oxygen. The process is performed in two stages. The first stage is drying, which is performed at temperatures close to $100{ }^{\circ} \mathrm{C}$ until the humidity is eliminated. In the second stage, HT is performed, thereby generating a vacuum, and increasing the temperature to $160{ }^{\circ} \mathrm{C}$ to $220{ }^{\circ} \mathrm{C}$. 


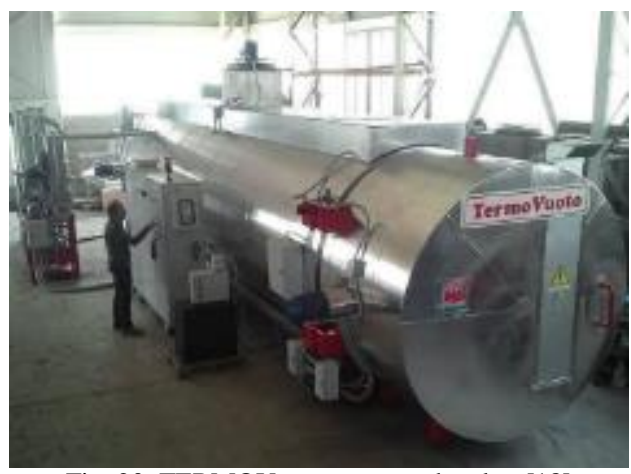

Fig. 20. TERMOVuoto process chamber [18]

This process is the most recently developed process. It was developed in the National Research Council of Italy within the framework of the Eco Innovation programmed [18].

Table 1 summarizes the main characteristics for each of the HT processes, among which marked differences can be observed among the pressure, temperature, atmosphere, moisture content, and commercial names currently used by the processes.

These wood HT technologies generate chemical reactions among cellulose, hemicellulose, lignin, extracts and environment. The objective of these treatments is to offer better physical characteristics in terms of duration and dimensional stability as well as better aesthetic aspects by homogenizing the color of the material. These technologies differ in magnitudes, such as temperature, time, and pressure, as well as based on the atmosphere in which each process is performed [22] [23] [27] [30].

Some technologies that have been reviewed in this study exhibit industrial protection, trademark registration and/or patent registration, which may be subsequently provided by other companies under different trademarks through commercial agreements (Table I) [31].

TABLE I.

SUMMARY OF THE HEAT TREATMENT COMMERCIAL TECHNOLOGIES IN WOOD [31]

\begin{tabular}{|c|c|c|c|c|c|c|c|c|}
\hline : & 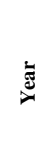 & 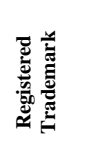 & 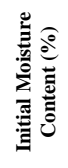 & 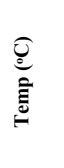 & 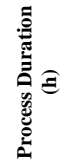 & 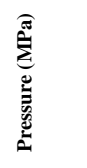 & 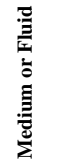 & 苞 \\
\hline FWD & $\begin{array}{l}19 \\
70\end{array}$ & $\begin{array}{l}\text { WTT® } \\
\text { Firmolin } \\
\circledR \text { ( }\end{array}$ & $\begin{array}{l}10- \\
30\end{array}$ & $\begin{array}{l}120- \\
180\end{array}$ & 15 & $0.5-0.6$ & Steam & $\begin{array}{l}\text { Closed } \\
\text { system }\end{array}$ \\
\hline Plato & $\begin{array}{l}19 \\
80\end{array}$ & $\begin{array}{l}\text { Platowoo } \\
d ®\end{array}$ & $\begin{array}{l}14- \\
18\end{array}$ & $\begin{array}{l}150- \\
180 / 1 \\
70- \\
190\end{array}$ & $\begin{array}{l}4- \\
5 / 70- \\
120 /> \\
336\end{array}$ & $\begin{array}{l}\text { Atmosp } \\
\text { heric } \\
\text { Pressure }\end{array}$ & $\begin{array}{l}\text { Saturat } \\
\text { ed } \\
\text { Steam/ } \\
\text { Hot } \\
\text { Air }\end{array}$ & $\begin{array}{l}\text { Four- } \\
\text { stage } \\
\text { process }\end{array}$ \\
\hline $\begin{array}{l}\text { Thermo } \\
\text { wood }\end{array}$ & $\begin{array}{l}19 \\
90\end{array}$ & $\begin{array}{l}\text { Thermow } \\
\operatorname{ood}{ }^{\circledR}\end{array}$ & $\begin{array}{l}10- \\
\text { gre } \\
\text { en }\end{array}$ & $\begin{array}{l}130 / 1 \\
85- \\
215 / 8 \\
0-90\end{array}$ & $30-70$ & $\begin{array}{l}\text { Atmosp } \\
\text { heric } \\
\text { Pressure }\end{array}$ & Steam & $\begin{array}{l}\text { Contin } \\
\text { uous } \\
\text { steam } \\
\text { flow }\end{array}$ \\
\hline $\begin{array}{l}\text { Le Bois } \\
\text { Perdure }\end{array}$ & $\begin{array}{l}19 \\
90\end{array}$ & Perdure ${ }^{\circledR}$ & $\begin{array}{l}\text { Gre } \\
\text { en }\end{array}$ & $\begin{array}{l}200- \\
230\end{array}$ & $12-36$ & $\begin{array}{l}\text { Atmosp } \\
\text { heric } \\
\text { Pressure }\end{array}$ & Steam & $\begin{array}{l}\text { Drying } \\
\text { and } \\
\text { Steam } \\
\text { Heat } \\
\text { treatme } \\
\text { nt }\end{array}$ \\
\hline
\end{tabular}

\begin{tabular}{|c|c|c|c|c|c|c|c|c|}
\hline $\begin{array}{l}\text { Rectifica } \\
\text { tion }\end{array}$ & $\begin{array}{l}19 \\
97\end{array}$ & $\begin{array}{l}\text { Retwood } \\
\circledR \text {, Bois } \\
\text { Retifié®, } \\
\text { Réti®, } \\
\text { Retibois® } \\
\text { Retitech }{ }^{\circledR} \\
\text { Retifier® }\end{array}$ & 12 & $\begin{array}{l}160- \\
240\end{array}$ & $8-24$ & N/A & $\begin{array}{l}\text { Nitrog } \\
\text { en or } \\
\text { other } \\
\text { inert } \\
\text { gases }\end{array}$ & $\begin{array}{l}\text { Nitroge } \\
\mathrm{n} \\
\text { guarant } \\
\text { ees that } \\
\text { there is } \\
\text { no } \\
\text { oxidati } \\
\text { on }\end{array}$ \\
\hline OHT & $\begin{array}{l}20 \\
00\end{array}$ & OHT® & $\begin{array}{l}\text { 10- } \\
\text { gre } \\
\text { en }\end{array}$ & $\begin{array}{l}180- \\
220\end{array}$ & $24-36$ & & $\begin{array}{l}\text { Vegeta } \\
\text { ble oil }\end{array}$ & $\begin{array}{l}\text { Closed } \\
\text { system }\end{array}$ \\
\hline TVT & $\begin{array}{l}20 \\
10\end{array}$ & $\begin{array}{l}\text { VacWood } \\
\text { ( }\end{array}$ & $0 \%$ & $\begin{array}{l}160- \\
220\end{array}$ & $\begin{array}{l}\text { More } \\
\text { than } \\
25\end{array}$ & $\begin{array}{l}\text { Vacuum } \\
150-350 \\
(1000) \\
\text { mbar }\end{array}$ & $\begin{array}{l}\text { Vacuu } \\
\mathrm{m}\end{array}$ & $\begin{array}{l}\text { Closed } \\
\text { system }\end{array}$ \\
\hline
\end{tabular}

There are other technologies reported in patent databases which were searched using International Patent Classification (CIP) and the Cooperative Patent Classification (CPC).

CIP and CPC are tools that allow the retrieval and methodical ordering of technical patent documents to access technological information and establish the state of the art around a specific topic. The difference between the IPC and the CCP is that the latter is more specific than the former. This is how these classifications are made up of a hierarchically organized alphanumeric code that goes from general to aspects, through sections, classes, subclasses, groups, and subgroups [32].

To carry out this review, free access patent databases were consulted (Spacenet Latinpat [33], Google Patents [34]). An initial search was carried out for keywords in Spanish and English, combining words as follows: "heat treatment in wood and wood modification" and "Wood heat treatment and wood modification and wood seasoning" respectively. This search resulted in relevant documents in the review, from which the alphanumeric codes of the CIP and CPC provided by the examiner were compiled [35]. An exploration was carried out using a keyword, CIP, CCP and the use of Booleans to narrow the search and find the relevant documents on the subject. Finally, the information on patents published in recent years was systematized. It should be noted that not every published patent is granted and that the CCP classification code does not appear for all patents due to the recentness of the classification (Table II).

TABLE II.

SUMMARY OF THE HEAT TREATMENT PATENTS TECHNOLOGIES IN WOOD

\begin{tabular}{|c|c|c|c|c|c|c|c|c|}
\hline 这 & $\underset{\nu}{\Xi}$ & 芯 & 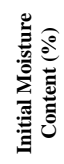 & 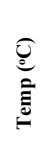 & 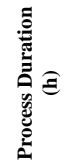 & 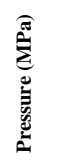 & 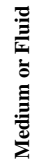 & 苞 \\
\hline $\begin{array}{l}\text { US983 } \\
3925 B \\
2\end{array}$ & $\begin{array}{l}20 \\
17\end{array}$ & $\begin{array}{l}\text { Manufact } \\
\text { uring } \\
\text { Method } \\
\text { For a } \\
\text { High } \\
\text { Durabilit } \\
\text { y, High } \\
\text { Insulating } \\
\text { Composit } \\
\text { e Timber } \\
\text { Member } \\
\text { and A } \\
\text { Composit } \\
\text { e Timber } \\
\text { Member }\end{array}$ & N/A & 173 & 6 & $\begin{array}{l}\text { Positive } \\
\text { pressure } \\
0.30- \\
1.52\end{array}$ & $\begin{array}{l}\text { Stea } \\
\text { m, } \\
\text { Air, } \\
\text { Inert } \\
\text { Gas }\end{array}$ & $\begin{array}{l}\text { Hybrid } \\
\text { method } \\
\text { carried } \\
\text { out by } \\
\text { increasin } \\
\mathrm{g} \text { the } \\
\text { temperat } \\
\text { ure and } \\
\text { by } \\
\text { impregna } \\
\text { tion in } \\
\text { the } \\
\text { material. }\end{array}$ \\
\hline
\end{tabular}




\begin{tabular}{|c|c|c|c|c|c|c|c|c|}
\hline $\begin{array}{l}\text { US917 } \\
0035 B \\
2\end{array}$ & $\begin{array}{l}20 \\
15\end{array}$ & $\begin{array}{l}\text { Apparatu } \\
\text { s and } \\
\text { Method } \\
\text { for } \\
\text { Thermo- } \\
\text { Transfor } \\
\text { mation of } \\
\text { Wood } \\
{[36]}\end{array}$ & Dry & $\begin{array}{l}\mathrm{N} / \\
\mathrm{A}\end{array}$ & N/A & $\begin{array}{l}\text { Atmosp } \\
\text { heric } \\
\text { pressure }\end{array}$ & Air & $\begin{array}{l}\text { The air is } \\
\text { reheated }\end{array}$ \\
\hline $\begin{array}{l}\text { EP288 } \\
9112 A \\
1\end{array}$ & $\begin{array}{l}20 \\
15\end{array}$ & $\begin{array}{l}\text { Method } \\
\text { for } \\
\text { hydrother } \\
\text { mal } \\
\text { treatment } \\
\text { of Wood } \\
{[37]}\end{array}$ & N/A & $\begin{array}{l}120 \\
160\end{array}$ & 11 & $\begin{array}{l}\text { Positive } \\
\text { pressure }\end{array}$ & $\begin{array}{l}\text { Stea } \\
\mathrm{m}\end{array}$ & $\begin{array}{l}\text { Hydrothe } \\
\text { rmal } \\
\text { treatment } \\
\text { that } \\
\text { allows } \\
\text { increasin } \\
\text { g the } \\
\text { hydropho } \\
\text { bicity of } \\
\text { the wood } \\
\text { at low } \\
\text { cost }\end{array}$ \\
\hline $\begin{array}{l}\text { ES252 } \\
8903 T \\
3\end{array}$ & $\begin{array}{l}20 \\
14\end{array}$ & $\begin{array}{l}\text { Apparatu } \\
\text { s } \\
\text { comprisin } \\
\text { g a } \\
\text { vacuum } \\
\text { autoclave } \\
\text { for the } \\
\text { modificat } \\
\text { ion of } \\
\text { high } \\
\text { temperatu } \\
\text { re wood. } \\
\text { [38] }\end{array}$ & N/A & $\begin{array}{l}160 \\
240\end{array}$ & 72 & $\begin{array}{l}\text { vacuum } \\
(0,007- \\
0,035)\end{array}$ & Air & $\begin{array}{l}\text { Micro } \\
\text { combusti } \\
\text { on or } \\
\text { self- } \\
\text { neutraliza } \\
\text { tion of } \\
\text { wood }\end{array}$ \\
\hline $\begin{array}{l}\text { US839 } \\
7400 B \\
2\end{array}$ & $\begin{array}{l}20 \\
13\end{array}$ & $\begin{array}{l}\text { High } \\
\text { Temperat } \\
\text { ure } \\
\text { Lumber } \\
\text { treatment } \\
\text { System } \\
{[39]}\end{array}$ & N/A & $\begin{array}{l}80- \\
200\end{array}$ & 36 & $\begin{array}{l}\text { Positive } \\
\text { pressure }\end{array}$ & $\begin{array}{l}\text { Stea } \\
\mathrm{m} \text {, air }\end{array}$ & $\begin{array}{l}\text { Two- } \\
\text { stage } \\
\text { heating } \\
\text { and } \\
\text { cooling / } \\
\text { Restrictio } \\
\mathrm{n} \text { with } \\
\text { external } \\
\text { load of at } \\
\text { least } \\
700 \mathrm{~kg} / \\
\mathrm{m}^{2}\end{array}$ \\
\hline $\begin{array}{l}\text { US634 } \\
5450 \mathrm{~B} \\
1\end{array}$ & $\begin{array}{l}20 \\
02\end{array}$ & $\begin{array}{l}\text { Process } \\
\text { for } \\
\text { Treating } \\
\text { Green } \\
\text { Wood } \\
\text { and for } \\
\text { Accelerat } \\
\text { ing } \\
\text { Drying } \\
\text { Of Green } \\
\text { Wood } \\
\text { [40] }\end{array}$ & Green & $\begin{array}{l}7 \\
65, \\
56\end{array}$ & $\begin{array}{l}23- \\
312\end{array}$ & $\begin{array}{l}\text { Atmosp } \\
\text { heric } \\
\text { pressure }\end{array}$ & Air & $\begin{array}{l}\text { Cooling } \\
\text { after } \\
\text { heating } \\
\text { causes } \\
\text { the "flash } \\
\text { off" } \\
\text { effect, } \\
\text { which is } \\
\text { the } \\
\text { novelty } \\
\text { claimed } \\
\text { by the } \\
\text { inventors, } \\
\text { which } \\
\text { consists } \\
\text { of an } \\
\text { increase } \\
\text { in the } \\
\text { permeabi } \\
\text { lity of the } \\
\text { wood that } \\
\text { is } \\
\text { sustained } \\
\text { until the } \\
\text { desired } \\
\text { moisture } \\
\text { content is } \\
\text { reached. }\end{array}$ \\
\hline $\begin{array}{l}\text { ES209 } \\
6996 T \\
3\end{array}$ & $\begin{array}{l}19 \\
94\end{array}$ & $\begin{array}{l}\text { Procedure } \\
\text { to } \\
\text { improve } \\
\text { the } \\
\text { quality of } \\
\text { low- } \\
\text { quality } \\
\text { wood } \\
\text { [41] }\end{array}$ & $\begin{array}{l}\text { Green } \\
/ \text { fresh } \\
\text { cut / } \\
67- \\
150\end{array}$ & $\begin{array}{l}160 \\
220\end{array}$ & 10 & $\begin{array}{l}\text { Averag } \\
\mathrm{e} \\
\text { aqueous } \\
\text { softenin } \\
\mathrm{g} \text { vapor } \\
\text { pressure } \\
\text { and } \\
0.010\end{array}$ & $\begin{array}{l}\text { Aque } \\
\text { ous } \\
\text { medi } \\
\text { um } \\
\text { (wate } \\
\text { r) }\end{array}$ & $\begin{array}{l}\text { It is a } \\
\text { process } \\
\text { in which } \\
\text { ohmic } \\
\text { heating is } \\
\text { used for } \\
\text { the } \\
\text { softening } \\
\text { stage and } \\
\text { for part } \\
\text { of the } \\
\text { drying, } \\
\text { then } \\
\text { conventio } \\
\text { nal } \\
\text { heating is } \\
\text { used }\end{array}$ \\
\hline
\end{tabular}

\section{CONCLUSIONS}

The studies that have been conducted by different researchers in the early twentieth century on issues related to drying at high temperatures served as the foundation for the development of technologies that are currently being applied in wood HT.

There has been considerable interest in the previous two decades in studies related to HTs that are applied to wood to improve the hygroscopic properties in soft woods and to obtain products that may be subjected to external environmental conditions such as outdoor furniture or floors.

The HTs that are applied to wood are a friendly alternative to the environment when compared to surface treatments or impregnation because chemical contaminants are not involved in their process.

There are different wood HT technologies, which can vary according to the medium, temperature, pressure, and time of treatment. Nitrogen gas, steam or oil may be used as the medium to prevent combustion. Depending on the pressure, these technologies can be performed at atmospheric pressure, positive pressure, negative pressure, or vacuum. All the technologies include various conditions to prevent the combustion of the material.

The HT programmers that are performed under the above technologies are observed to vary according to the nature of the species and the purpose of the wood. Researchers are currently investigating the optimal conditions for performing HTs by minimizing the physical and mechanical properties of the material.

There are different mechanisms to heat the wood and treat it thermally, some methodologies use conventional heating, others use ohmic heating and some a combination of the two previous [42].

The most common heating fluids are air and steam, oils and molten metals can also be used [43]. The atmospheres can vary with positive or negative pressure, with steam or with inert gases which prevent combustion in the material.

The exposed methodologies have at least in common the stages of heating, treatment, and cooling, and they avoid that there is combustion in the material directly [44] [42] [45] [46] [47] [48] [43].

Wood modified by heat treatments is used in construction slats, floors, beams, columns, panels, and structural and decorative elements with outdoor uses [49] [50].

Most of the methodologies found work through potholes since some require a vacuum to lower the vapor pressure temperature and dry the product later. 
For future work, it is recommended to carry out an energy analysis of the different heat treatment technologies applied to wood to establish possible associated costs.

\section{ACKNOWLEDGMENT}

The authors thank the Technological University of Pereira, Project 9-17-7. On behalf of all authors, the corresponding author declares that there is no conflict of interest.

\section{REFERENCES}

[1] M. R. Pelaez Samaniego, V. Yadama, L. Eini y R. Espinoza Herrera, "A review of wood thermal pretreatments to improve wood composite propierties," Springer, vol. 47, pp. 1285-1319, 2013. DOI: $10.1007 / \mathrm{s} 00226-013-0574-3$

[2] C. A. S. Hill, Wood Modification: Chemical, Thermal and Other Processes, Bangor: John Wiley \& Sons, Ltd, 2006. DOI: $\underline{10.1002 / 0470021748}$

[3] D. Sanderberg y P. Navi, Introduction to Thermo-hydromechanical (THM) Wood Processing, Suiza: Vaxjo University , 2007.

[4] M. A. Majano Majano, Madera termo-tratada de frondosas para uso estructural, Madrid: Universidad Politécnica de Madrid, 2014.

[5] P. Klaas. [En línea]. Available: http://www.wtt.dk/app/webroot/uploads/Documents/ThermoTreat \%202.0_Product\%20Presentation.pdf. [Último acceso: 19 mayo 2018].

[6] A. O. Rapp, Review on heat treatments of wood, Hamburg: The European Commission Research Directorate, 2001.

[7] SCOPUS, [En línea]. Available: https://www-sciencedirect-com. [Último acceso: 5 Marzo 2018].

[8] H. Tiemann, "The effect of different methods od drying on the strength of wood," Lumber World Review, vol. 28, n 2, pp. 19-20, 1915.

[9] F. Kollmann, Technologie des Holzes und der Holzwerkstoffe, Berlin: Springer Verlag, 1936.

[10] Lignostone Corporation, "Lignostone Corporation," [En línea]. Available: http://www.lignostone.com/. [Ultimo acceso: 1502 2021].

[11] A. J. Stamm y L. A. Hansen, Minimizing Wood Shrinkage an Swelling Effect of Heating in Various Gases, Madison, Wisconsin: U.S. Department of Agriculture, Forest Service, 1937. DOI: $\underline{10.1021 / \mathrm{ie} 50331 \mathrm{a} 021}$

[12] A. J. Stamm, "Antishrink Treatment for Wood". United States of America Patente 2296316, 22 septiembre 1942.

[13] A. J. Stamm, R. M. Seborg y M. A. Millet, "Method of Forming Compressed Wood Structures". Estados Unidos de América Patente 2453679, 9 noviembre 1948.

[14] M. Seborg, H. Tarkow y A. J. Stamm, "Effect of Heat Upon the Dimensional Stabilization of Wood," Office of naval Research Inform, Milwaukee, 1952.

[15] A. Stamm, H. K. Burr y A. A. Kline, "Heat Stabilized Wood (Staywood)," Forest Products Laboratory, n 1621, 1955.

[16] R. M. Seborg, M. A. Millet y A. J. Stamm, "Heat_Stabilized Compressed Wood (Staypak)," Forest Products Laboratory, Madison, 1956.

[17] W. J. Homan y A. J. Jorissen, "Wood modification development," HERON, vol. 49, nº 4, p. 26, 2004.
O. Dagbro, "Doctoral Thesis Studies on Industrial-Scale Thermal Modification of Wood," Lulea University of Technology, Suiza, 2016.

Platowood B.V., "Platowood B.V." Platowood BV, 2018. [En línea]. Available: https://www.platowood.com. [Último acceso: 9 mayo 2018].

H. P. Ruyter y P. Arnoldy, "Procedimiento para mejorar la calidad de madera de baja calidad". España Patente ES2091087, 27 Marzo 1994.

[21] H. Ruyter y A. Hortulanus, "Process for Upgrading Low-Quality Wood". Estados Unidos Patente US005451361A, 19 Septiembre 1995.

[22] M. Holger y T. Boke, "Heat tratment of wood by the Platoprocess," Nordic Wood.

[23] Finnish Thermowood Association, Termowood Handbook, Finlandia, 2003.

[24] Jartek Invest, “Jartek Invest,” Imager, 2017. [En línea]. Available: http://www.jartek.fi/en/solutions/thermowood-kilns. [Último acceso: 9 mayo 2018].

[25] J. P. Bernon, B. Robert, F. Robert y J. Drevet, "Apparatus and Method for The Treatment of Lignocellulosic Material". USA Patente WO2004/045815A2, 3 june 2004.

[26] M. Josset y E. Masson, "Le traitement haute température du bois," de Ressources Transferts Technologiques, France, 2015.

[27] A. Rapp O y S. Michael, "Heat treatment of wood in Germanystate of the art," Bundesforschungsanstalt für Forst- und Holzwirtschaft.

[28] I. A. Danchenko, "Method for wood heat treatment and a device for carrying out said method". Estados Unidos Patente US 20110020568A1 , 27 junio 2011.

[29] W. H. T. L. CORPORATION, "Westwoodcorporation," 7 mayo 2018. [En línea]. Available: http://www.westwoodcorporation.com/Research.html. [Último acceso: 7 mayo 2018].

[30] T. Syrjänen y K. Oy, "Heat treatment of wood in Finland Finlandstate," Finland.

[31] D. Sandberg y A. Kutnar, "Thermally Modified Timber: Recent Developments In Europe And North America," Wood and fiber science, vol. 48, pp. 28-39, 2016.

[32] Oficina Española de Patentes y Marcas, "Oficina Española de Patentes y Marcas," [En línea]. Available: http://cip.oepm.es/. [Último acceso: 13 Febrero 2018].

[33] Espacenet patent search, "Espacenet patent search," [En línea] Available: https://lp.espacenet.com/. [Último acceso: 5 Febrero 2018].

[34] Google LLC, "Google LLC," [En línea]. Available: https://patents.google.com/advanced. [Último acceso: 5 Febrero 2018].

[35] World Internacional Property Organization, "World International Property Organization," [En línea]. Available: http://www.wipo.int/classifications/ipc/. [Último acceso: 30 Enero 2017].

[36] G. Prud'homme, "Apparatus and Method For ThermoTransformation Of Wood". USA Patente US9170035B2, 27 octubre 2015.

[37] I. Andersone, B. Andersons, D. Cirule, V. Biziks, J. Cirkova, J. Grinins, I. Irbe, N. Kurnosova y E. Sansonetti, "Method for hydrothermal treatment of Wood". Europa Patente EP2889112A1, 7 enero 2015

[38] E. Pagnozzi, "Aparato que comprende una autoclave de vacìo para la modificaciòn de madera de alta temperatura". España Patent ES2528903T3, 14 junio 2012.

[39] K. T. Choo y H. S. Sik, "High Temperature Lumber treatment System". USA Patente US8397400B2, 19 march 2013.

[40] D. J. Elder, "Process for Treating Green Wood and for Accelerating Drying Of Green Wood". USA Patente US6345450B1, 2002. 
[41] P. C. Rem, H. Van Der Poel y H. P. Ruyter, "Procedimiento para mejorar la calidad de madera de baja calidad". España Patente ES2096996T3, 1994.

[42] P. C. Rem, H. Van Der Poel y H. P. Ruyter, "Procedimiento para mejorar la calidad de madera de baja calidad". Europa Patente ES2096996T3, 31 Agosto 1994.

[43] D. J. Elder, "Process for Treating Green Wood and for Accelerating Drying Of Green Wood". Estado Unidos de América Patente US6345450B1, 12022002.

[44] E. Pagnozzi, "Aparato que comprende una autoclave de vacìo para la modificaciòn de madera de alta temperatura". España Patente ES2528903T3, 14 Junio 2012.

[45] I. Andersone, B. Andersons, D. Cirule, V. Biziks, J. Cirkova, J. Grinins, I. Irbe, N. Kurnosova y E. Sansonetti, "Method for hydrothermal treatment of Wood". Europa Patente EP2889112A1, 7 Enero 2015.

[46] A. Lars Hojmann Kristensen y H. Finn Borg, "Manufacturing Method For a High Durability, High Insulating Composite Timber Member and A Composite Timber Member". USA Patente US 9,833,925 B2, 5 December 2017.

[47] K. T. Choo y H. S. Sik, "High Temperature Lumber treatment System”. United States Patente US8397400B2, 19 March 2013.

[48] G. Prud'homme, "Apparatus and Method For ThermoTransformation Of Wood". USA Patente US 9,170,035B2, 27 octubre 2015.

[49] Wood Protection Association, "WPA," [En línea]. Available: https://www.thewpa.org.uk/wood-modification. [Último acceso: 2 june 2021].

[50] Wood Treatment Association, "WTA,” [En línea]. Available: https://wtt.global/. [Último acceso: 2 june 2021].

[51] M. Vernois, "Heat treatment of wood in France -state of the art," NordicWood.

[52] A. Lars Hojmann Kristensen and H. Finn Borg, "Manufacturing Method For a High Durability, High Insulating Composite Timber Member and A Composite Timber Member". USA Patent US9833925B2, 5 December 2017.

[53] International ThermoWood Association, "ITWA," [En línea]. Available: https://www.thermowood.fi/. [Último acceso: 2 june 2021].

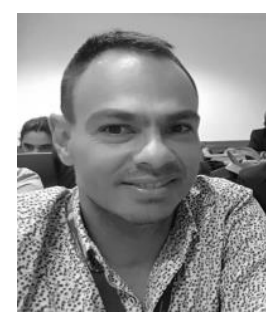

Ricardo Acosta Acosta

Professor Technological University of Pereira. Doctoral Candidate and M.Sc. Automatic Production Systems and Mechanical Engineer, Technological University of Pereira.

ORCID: https://orcid.org/0000-0001-7174-7281

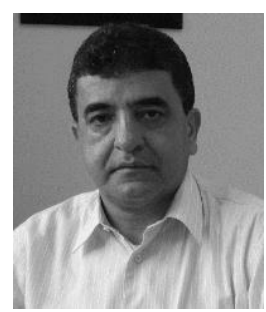

\section{Jorge Augusto Montoya Arango}

Professor Technological University of Pereira. Ph.D. Nature Sciences, Hamburg University. M.Sc. Environment and Development, National of Colombia University and Mechanical Engineer, Technological University of Pereira.

ORCID: https://orcid.org/0000-0003-3778-7727

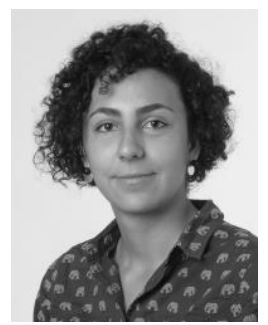

\section{Emilin Joma da Silva}

Doctoral candidate at University Hamburg. M.Sc. Wood Sciences and Technology at the University Hamburg. Graduation at Federal University of Parana, Brazil. Academic exchange during graduation at University Hamburg, Germany.

ORCID: https://orcid.org/0000-0002-4291-7867 